\title{
The Development of Comic Book as Marker of Augmented Reality to Raise Students' Critical Thinking
}

\author{
Insar Damopolii, Fridolin Febrianto Paiki, Jan Hendriek Nunaki
}

Universitas Papua, Gunung Salju Street, Manokwari, Indonesia

\begin{abstract}
Critical thinking (CT) in biology is important for future learners. The examination results from previous studies are complemented by the author's initial findings showing that students' $\mathrm{CT}$ is not well developed. This research develops comic books as Augmented Reality (AR) markers to raise students' CT. ADDIE model is used in this research. The scaletest was limited to twenty rural high school students. Validation sheets, CT tests, and questionnaires were used to collect data. The research results show that comic books and AR are valid based on expert evaluation. Limited scale trial of moderate improvement in student CT (n-gain $=0.38$ ). $75 \%$ of students' CT has developed well at the end of the lesson. There is a significant difference between pre$\mathrm{CT}$ and post-CT $(\mathrm{p}<0.05)$. Students respond excellently to the use of comic books as AR markers in learning. This research concludes that comic books and $A R$ are valid and their use in learning during a pandemic can improve students' CT. Recommendations for future research are trials on a large scale to determine the strong effectiveness of using comic books as AR markers.
\end{abstract}

Keywords - augmented reality, comic, critical thinking, science learning.

DOI: $10.18421 /$ TEM111-44

https://doi.org/10.18421/TEM111-44

Corresponding author: Insar Damopolii,

Universitas Papua, Gunung Salju Street,

Manokwari, Indonesia.

Email: i.damopoli@unipa.ac.id

Received: 14 November 2021.

Revised: 05 February 2022.

Accepted: 11 February 2022.

Published: 28 February 2022.

(c) BY-NC-ND (C) 2022 Insar Damopolii, Fridolin Febrianto Paiki \& Jan Hendriek Nunaki; published by UIKTEN. This work is licensed under the Creative Commons AttributionNonCommercial-NoDerivs 4.0 License.

The article is published with Open Access at https://www.temjournal.com/

\section{Introduction}

Critical thinking (CT) is a skill that has to be empowered in the curriculum in Indonesia. CT is one of four other skills: communication, collaboration, and creativity (called 4Cs). In Indonesia, the CT of 202 high school students has been measured [1]. The results of their measurements revealed that there were $50.49 \%$ of students with less developed CT. Critical thinking is connected with students' cognitive abilities. The low CT is considered due to the students' cognitive abilities being weak and not being empowered. During school closures in the pandemic era it has caused students' CT not to develop properly. The 2021 publication by Fajari and Chumdari [2] found that $86 \%$ of students did not meet class standards when they took the CT test. This research also found that $44 \%$ of students have less developed CT because they were below the average class score. Preliminary studies have been carried out to identify students' CT during the pandemic, especially in biology class. The findings showed that the mean CT of the students is 41.6. Preliminary findings also showed that $89 \%$ of students did not develop well in their CT.

Empowerment of students' CT can be supported by providing learning resources in accordance with current conditions. Digital-based innovative and creative learning resources can improve students' cognitive and support them to succeed [3]. Digital learning resources have been widely used to support online learning during a pandemic. The abundant learning resources apparently cannot help clarify a learning material but cause a burden on memory, weaken the learning process, and decrease students' critical thinking skills. Selecting and sorting out the types of learning resources is vital to empower students' CT.

Science classes must be oriented to managing students' critical thinking with the aim of being critical to confront fake news being circulated [4]. The low level of students' CT during the pandemic was caused by a poor internet connection to support 
them in conducting discussions as in face-to-face learning. Students must be able to obtain information from a media that can be trusted. Puig et al. [4] revealed that in order to encourage students' CT, learning content and resources must support the development of CT. The author argues that teachers must provide reliable information by providing accurate learning media and scientific facts. Nowadays, technology in education must adapt to the development and needs of students so that they can express themselves and optimize their cognitive. During the pandemic, science teachers were challenged to use online learning technology to keep their students learning.

Digital technology and online learning have shifted physical learning, which was implemented before the pandemic crisis. Technology and digital learning have made students learning and communicating virtually [5]. The challenge in education is to provide learning resources compatible with the latest educational conditions. Digital products used in online learning must be in accordance with the available infrastructure so that students' performance can be optimized [6]. The limitations of laboratory space can be overcome with technology so that students can still observe objects as they did initially. Augmented reality (AR) enhances traditional learning resources that are difficult to obtain through real experience [7], [8]. The research conducted by Weshah et al. [9] aims to overcome the impracticality of the learning process and the inability of students to understand concepts by creating AR for android-based smartphones. Their findings reveal that AR creates conditions where students (users) and virtual objects are in the same physical space so that students' inability to understand abstract concepts can be overcome.

Teachers believe that their students can be engaged and enjoy online learning using AR integrated books [10]. These researchers used AR books to evaluate their students. The obstacle faced is that AR books require internet access, and some students do not register for internet data packages. The researchers suggest that the use of the application must be preceded by the need and ability of its users so that they can gain access. Hedberg et al. [11] reviewed articles published over seventeen years (2000 2017) that focus on AR. The data shows that the use of $\mathrm{AR}$ is more dominant at the university and elementary school levels. Only $8.22 \%$ of the articles reviewed conducted research on the use of the AR at the high school level. This review also found that more of the content studied was on natural science topics and more focused on increasing students' motivation and involvement in learning. They did not display the data on articles that are discussing the improvement of students' CT. Research for high school students' CT using AR is necessary because there are few focuses on this.

A review article in 2019 by Arici et al. [12] on the use of the AR in science reveals that AR is widely used in mobile devices, and studies are more dominant in its impact on student achievement and attitudes motivation in science. Only one $(1.61 \%)$ of the total reviewed articles studied CT. The results of this study prove that CT has not been widely studied in scientific research using AR. The article in 2020 by Sahin and Yilmaz [13] found that science material full of abstract concepts has caused a gradual decline in student interest and student achievement. This researcher provides a solution through research in an AR-based booklet design and compares it with textbooks in conventional learning in science classes. The shape of the three-dimensional object displayed from the booklet is emitted onto the board to be observed by students. They found no anxiety in students, and students' achievement and attitudes towards science are increased.

The latest article in 2021 by Faridi et al. [14] has created an AR-based learning environment to improve students' CT in physics. They used a marker to detect the camera from the AR application and display a three-dimensional shape. Students' CT was measured at the end of the lesson and compared with the non-AR group. The research results show that AR has an impact on students' CT because students are involved in learning activities, encourage learning motivation, and visualize abstract concepts. The researchers stated that AR could be developed during the pandemic to support teachers in creating effective learning environments.

Digital-based learning resources equipped with illustrations in pictures can be an additional alternative to encourage students' online learning interest. In science fields such as biology, the use of AR to promote student attitude and learning outcomes has been studied [15]. However, this researcher has not revealed its impact on students' $\mathrm{CT}$, and a sheet of paper is used as an AR marker. We think that providing learning resources in comics as AR markers can support students even though they do not have internet data packages. The design of the AR-integrated learning resources must consider the existing facilities and the ability of students to use them. Comics in print are suitable as markers for AR. Students do not need to buy data packages if they do not have the money. They install the AR application on their smartphone device and expose it to the comics to display 3D shapes of anatomical structures.

Comics contain pictures that illustrate an event through a story. Comics contain a combination of text and images [16]. The text helps explain the events in the picture. Natural life phenomena and science concepts can be built into comic storylines 
[17]. Stories in comics attract students' attention. Comics can not only explain abstract science concepts, but can also provide humor, contextualize learning and visualize objects [18], [19]. Comics can help empower students' CT compared to students in non-comic classes [20]. The downside of comic books is that they cannot display 3D shapes. Designing a comic book as an AR marker is an innovative idea.

Yusof and Masmuzidin [21] investigated the effectiveness of the AR-assisted storybooks on Malaysian school children. These researchers found that the AR-assisted storybooks could increase students' interest, improve their mood, quickly understand the stories, be easy to read and be useful. Unfortunately, this research has not measured how the combination of the two can empower students' CT. Thus, this research aims to develop comic books as AR markers to raise students' $\mathrm{CT}$ in biology learning.

\section{Method}

This research develops a product in the form of comic books (print version) and AR. Product development follows the ADDIE model (analysis, design, development, implementation, evaluation) [22].

The participants consisted of four lecturers who are experts in biology, learning, and learning media. One teacher and twenty $11^{\text {th }}$ grade science students of public high school. The school is geographically located in a rural area. Even though it is located in a rural area, it can be reached by internet access. Internet conditions are less stable, so this is the basis for using comics and AR. Students involved in this research voluntarily become participants. They were given an initial explanation before using comic books as AR markers.

The analysis stage is done by measuring students' critical thinking. Students' learning resources are identified to determine their availability. During the stage design, comic and AR storyboards were designed. The material of the coordination system is set as the topic of the story in the comic. Three main characters were invented: Diva (character as a child and adult), Ato (character as a child and adult), and one supporting character, namely a biology teacher. In the development stage, comic and AR media are made.

The first comic media was made according to the designed storyboard. The characters and storylines are sketched on paper. One by one, the comic pages are drawn using a pencil. The images are scanned and digitally sketched using the Sketchbook application. Text and word bubbles are created using PicsArt Photo Editor. AR was created with the help of unity3D and the Vuforia SDK and made primarily based on .apk files (for android devices). Limited scale trial in public high school with pre-test - posttest design. An evaluation was carried out to determine the strength of the product developed to increase students' CT.

Data are collected using validation sheets, questionnaires, and tests. Lesson plans are also used to facilitate the learning process. Validation sheets are used by learning experts and learning media to measure product validity. Validation sheets are used during the development stage. Experts give a score of $1-4$ for each aspect that is measured. The student response questionnaire contains 22 statements with a scale of $1-4$. The questionnaire is given at the end of the lesson. The test used in this research measures students' critical thinking (referred to as CTT). The CTT is administered before the study is performed, and these initial CT data are called pre-CT. The second measurement is done after students learn with comics and AR media. Data collected on the second measurement is called post-CT. The CTT is compiled based on the indicators studied by Mapeala and Siew [23]. The indicators of CT are (1) comparing and contrasting, (2) sequencing, and (3) identifying cause-effects. The total number of CTTs is 26 $($ Cronbach's alpha $=0.91)$.

The eligibility of comic books and AR was calculated based on the score given by the expert, the improvement of the student's CT, and the student's response. Criteria for validity is calculated using the Akbar formula [24]. The product is valid if the score is between $80-100$ (without revision). The product is valid, and minor revisions are made if it gets a $70-$ 84. The product is valid and significant revision is made if it gets a score of $50-69$. The product is invalid if the score is below 50. Normalized gain (ngain) is calculated to measure the increase in students' CT. The difference between pre-CT and post-CT is calculated using the related t-test. The normality test of CT data is calculated using Kolmogorov Smirnov. Effect size $(d)$ is calculated by Dunlap's formula [25].

Students' CT level results are categorized into five categories in Iwan et al. [26]. The CT categories are excellently developed $(80-100)$, well developed (60 - 79), moderately developed (40 - 59), less developed $(20-39)$, and CT is undeveloped for a score below 20 .

\section{Result and Discussion}

This research aims to produce comic books as AR markers. Comic books and AR as a solution for online learning in the pandemic era. The product that has been produced is tested for validity through an assessment by an expert. The results of the validity calculation are presented in Table 1. 
Table 1. Assessment of product validity

\begin{tabular}{||ccc||}
\hline \multicolumn{1}{|c}{ Assessment } & $\begin{array}{c}\text { Score } \\
\text { Comic book }\end{array}$ & Validity \\
Material expert & 87.50 & Yes \\
Learning expert & 83.93 & Yes \\
Media expert & 97.50 & Yes \\
& AR & \\
Material expert & 95.00 & Yes \\
Learning expert & 96.15 & Yes \\
Media expert & 100 & Yes \\
\multicolumn{2}{l}{ CTT and Lesson Plan } & \\
Lesson Plan & 91.67 & Yes \\
\hline \hline
\end{tabular}

Products that have been designed meet the criteria for validity based on experts. The scores obtained indicate that comic books, AR, lessons, and critical thinking tests can be used to collect data.

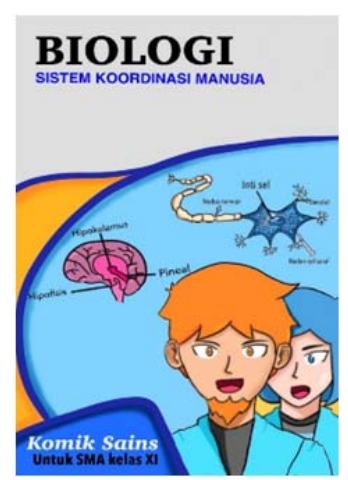

a. Front cover

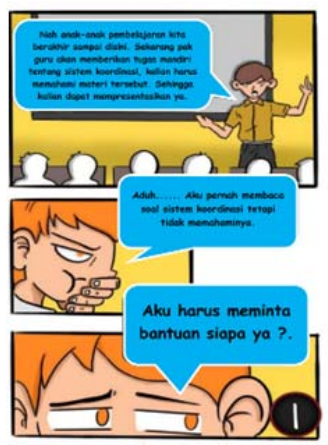

c. First page

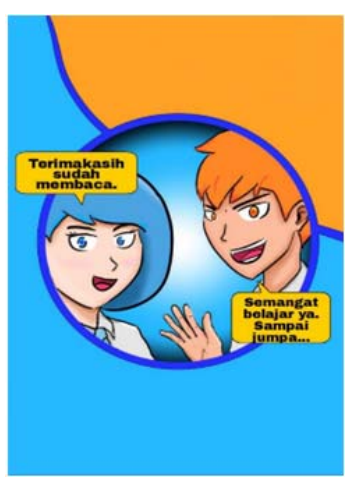

b. Back cover

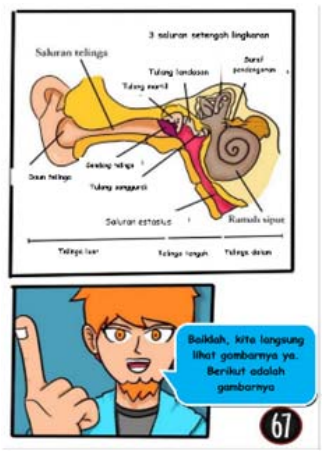

d. Content page
Figure 1. Comic book

Figure 1. shows the cover (front and back) and content of the designed comic book. The subject matter in comic books is about the human coordination system. This comic book is designed for $11^{\text {th }}$ grade science students. The first page of the comic opens with teaching and learning activities in the classroom. The biology teacher ends the learning activity by giving assignments for students to do at home. The teacher's character only appears on this first page. Figure 1.d shows the biology material content section. In this section, there is an image of the ear which is a marker for AR applications. When students point their smartphones towards the ear image, a three-dimensional image will be displayed on the smartphone layer.

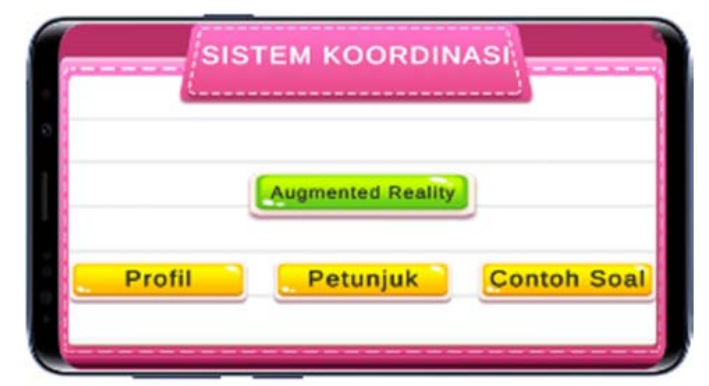

a. AR in mobile device

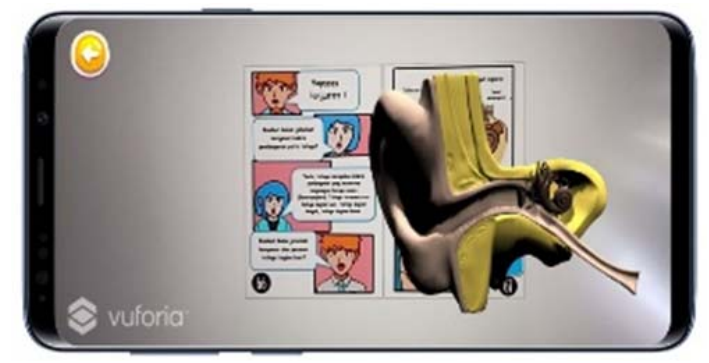

b. 3D image of ear

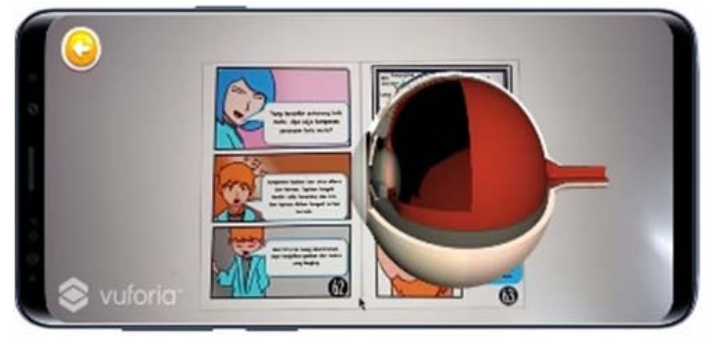

c. $3 D$ image of eye

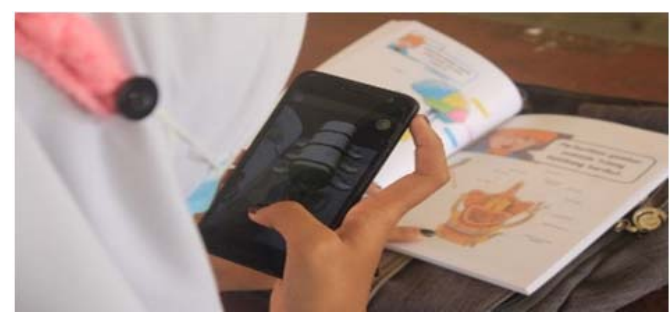

d. Trial by student

Figure 2. AR and organ 3D images display

Figure 2.a presents the menu view from AR. In this view, there are four main menus, namely maker profiles, instructions, tests, and augmented reality. When students click on the augmented reality menu, they will point to the camera and aim at the markers available in comic books. The shape of the 3D image is shown in Figures 2.b and 2.c. Figure 2.d shows a trial of the use of comics by students. The trial was conducted on all participants $(\mathrm{N}=20)$ in this research.

Table 2. Mean, standard deviation (SD) and n-gain of students ' $C T$

\begin{tabular}{|lllcc|}
\hline \multicolumn{1}{|c}{ Data } & N & Mean & SD & n-gain \\
Pre-CT & 20 & 50.32 & 13.31 & 0.38 \\
Post-CT & 20 & 69.10 & 16.55 & \\
\hline
\end{tabular}


The findings presented in Table 2. revealed that the students' pre-CT was at a moderately developed level. The post-CT data showed a mean of 69.10 , which indicated that the students' CT had increased. The score revealed that the students' CT reached a well-developed level. The difference between these two scores is 18.78 . When calculating the increase in CT students, the n-gain value is 0.38 . This score revealed that there is a moderate improvement in the student's CT. Then the CT level of students is presented in Table 3.

Table 3. CT level of students

\begin{tabular}{|c|c|c|}
\hline \multirow[t]{2}{*}{ Level } & \multicolumn{2}{|c|}{$\begin{array}{c}\text { Number of Students and } \\
\text { Percentage }\end{array}$} \\
\hline & Pre-CT & Post-CT \\
\hline Undeveloped & $7(35 \%)$ & $0(0 \%)$ \\
\hline Less Developed & $6(30 \%)$ & $1(5 \%)$ \\
\hline Moderately Developed & $7(35 \%)$ & $4(20 \%)$ \\
\hline Well Developed & $0(0 \%)$ & $10(50 \%)$ \\
\hline Excellently Developed & $0(0 \%)$ & $5(25 \%)$ \\
\hline
\end{tabular}

The findings on the CT level of students revealed that at the beginning of the CT, none of the students are well developed or excellently developed. Most of the students are at the undeveloped and moderately developed level (each percentage of both is $35 \%$ ). The remaining $30 \%$ of students are in the less developed category. The use of comic books as AR markers changes students' CT for the better. The findings showed that as many as $50 \%$ of students had well-developed CT. $25 \%$ of students even reached the level of excellently developed. There are still $20 \%$ of moderately developed students, and $5 \%$ are less developed. There is no single student whose CT is undeveloped when using comic books as an $\mathrm{AR}$ marker. Final findings indicated that $75 \%$ of the CT students progressed well. The remaining $25 \%$ need to have a CT upgrade. Furthermore, Table 4. presents the results of testing the differences between pre-CT and post-CT.

Table 4. Related t-test result of students' $C T$

\begin{tabular}{||cccccccc||}
\hline Pair & $\mathrm{r}_{12}$ & Mean & SD & $\mathrm{t}$ & $\mathrm{df}$ & $p$ & $d$ \\
Post-CT - & 0.69 & 18.78 & 12.13 & 6.93 & 19 & 0.00 & 1.22 \\
Pre-CT & 0.62 & \\
\hline
\end{tabular}

The test results indicate that pre-CT and post-CT are significantly different $(p=0.00<0.05$. This finding reveals that the use of comic books as an AR marker changes students' CT. The d value is 1.22 , indicating a strong effect of using comic books as an AR marker to raise students' CT. This research indicates that the use of comic books as AR markers effectively raises students' CT. This research also measures students' responses to the use of comic books as AR markers. Table 5. presents the student's responses.

Table 5. Students' response towards comic books and AR

No

No
1 The title of the comic is in accordance with the content of the lesson presented

The cover display attracts attention to reading comics

3 The language used is simple and easy to understand

4 The material in the comic is very easy to understand

5 The pictures on this biology comic page are very clear and make it easier for me to learn

6 I feel that using this biology comic can motivate me to study

7 The comic storyline makes me enjoy reading the contents of the comic

8 The writing on this development comic is very clear and easy to read

The material presented can stimulate critical thinking

10 The contents of the comic story contain accurate coordination system information

11 Comic media facilitates the learning process on coordination system materials

12 Characters / figures in the comic are interesting to read

13 Comic helps to increase the intensity of selfstudy

14 I am interested in using comics learning media with AR applications

$153 \mathrm{D}$ drawing in AR made me learn more about the coordination system material in comic The compatibility of $3 \mathrm{D}$ images in AR with

16 images in comic makes it easier for me to learn

The use of AR-based learning media makes it

17 easier for me to learn because I can see real pictures on the coordination system material

This AR media makes me want to continue to

18 search and find out more about coordination system materials

I feel amazed to see certain pictures on the

19 coordination system material because it looks real

20 The sample questions contained in AR media helped me to solve critical thinking questions I can relate the content of AR media to things

21 I have seen, done, or thought about in my daily life

The content on AR media during this learning gives a valuable impression starting from

22 knowledge, ways of thinking to solve problems contained in the coordination system material

Average

Students' responses to the use of comic books as AR markers are 84.5. These findings indicate that they respond excellently to comic books as an AR media in learning. Students gave three statements a good response. The first statement is that the material in comics is very easy to understand, with a response 
of $79 \%$. The second statement is that the characters/figures in the comics attract attention to read with a response of $74 \%$. The third statement is that I can relate the content of AR media to things I have seen, done, or thought about in my daily life, with a response rate of $76 \%$. The remaining 19 statements were answered excellently. There are no statements that get a poor response from students. Therefore, the use of comic books as AR markers makes students interested in reading and studying diligently.

This study has designed a comic book as an AR marker and evaluated its use to raise students' CT. The student learning environment is transformed into active and interactive learning. Due to the pandemic, the limited school facilities to conduct experiments and school closures caused learning conditions unimproved. In this research, comic books are designed, and AR displays three-dimensional images in comics. The designed comics and AR are judged to have usefulness by experts. The development of a teaching material must pay attention to the material and pedagogical aspects [27]. Experts in learning media, materials, and biology learning have provided an assessment, and it was decided that the designed product was valid and suitable for classroom teaching.

Three-dimensional shapes such as ears, human nerves, eyes, skin, and others in the material of the coordination system can be displayed through AR scanning on these images in comics. The comic is arranged to tell how two friends seek information by heading towards their future as they grow up. The image presented in the comic is used as a marker for AR. Some researchers may use an animal's black and white image as an AR marker [28]. In our research, the AR markers used are cartoon images of human organs (see Figure 1.d). The picture is made into a cartoon because it adapts to the compiled learning resources, namely comic books. The direction of the smartphone camera that has been installed with AR will display a three-dimensional image of the targeted organ. The use of these two products makes it easier for students to study online during the pandemic. The limitations of the internet network that many students complain about can be overcome through comic media. Comic media is made in printed form to facilitate student access because all students only have one smartphone. AR installed on students' smartphones also does not require internet access. Using both is cost-effective and easy to use.

$\mathrm{AR}$ is used as an additional tool to help students understand the anatomy of the human body [29]. In this research, researchers use AR as an additional tool to visualize images in comic books into threedimensional shapes. The images in comic books are related to the content of the human coordination system. This material covers the nervous system, hormones, and sensory systems, containing many abstract concepts. Students need a form of accurate visualization of the organs in the system. Parts of the brain such as the cerebellum, spinal cord, and other parts of the nerves can be assisted with threedimensional visualization using AR [30], [31]. The presence of comic books is intended to attract students' attention to read the material. Facts about biological phenomena and anatomical structures are presented in comic books to support students to think properly. Optimization of organ visualization in the coordination system is assisted by AR. Comic books become markers so that three-dimensional images can be displayed.

Several studies have reported the use of comic books, likewise with the use of AR. However, the use of both has not been much, which is what this research has done. The combination of the two is a new design in biology learning. If previous research used the two separately, in this research, the two products were combined. The three-dimensional view helps students to think deeply about the material. They can trace every detail of the organ, for example, the ear's anatomy (see Figure 2.b).

Weng et al. [15] have developed an AR integrated learning resource. The difference found by the researcher with what we did is in the shape of the marker. This researcher used books to provide scientific information, and students scan to display $3 \mathrm{D}$ objects. The research we have done is designing biological information about the human coordination system through a story in a comic. Students can display 3D shapes of human organs by pointing their smartphone cameras at 2D images in comics. Here, while reading the biological information presented in the comics, students can further explore the shape and the inside of the organ (e.g., the inside of the ear organ).

Students cannot observe the inside of the ear organ to find out how to enter sound into the human body. There are already stories about how the human process can hear sounds in the comics, but the curiosity of the parts that are passed in the ear organ is observed through the 3D images displayed. Thus, students can correctly sequence the incoming sound process until humans can hear it. This process trains sequencing skills which is one of the CT indicators. The 3D display that presents objects in real forms stimulates curiosity, students' scientific attitude, and empowers CT skills [32].

The observations made by students on threedimensional objects displayed by AR made them critical [33]. In this research, it is proven by the significant difference between pre-CT and post-CT students. Comic books as AR markers have had a significant effect, as indicated by the d value of 1.22 . 
Students can compare, sequence, and identify cause and effect when they study with the help of comic books as AR markers. Students' understanding of the anatomical structure of the organs of the coordination system makes them able to distinguish or compare. Organ structures displayed in three-dimensional form enable students to determine the paths traversed by impulses in human organs, such as the eye. That ability is part of critical thinking. Students are trained in $\mathrm{CT}$ as long as they learn to use comic books as AR markers.

Students' responses to the use of comic books as AR markers reached the excellent category. These findings indicate that they are interested in the product that has been used. The appearance and content of comic stories attract their attention to read them. Students were amazed by the 3D display presented in the AR application. They can easily display the 3D shape of an organ by simply pointing the AR app at the markers in the comics. Students' excellent responses indicated that they agreed with storybooks and AR used in learning to empower their CT [34].

During the pandemic, many students were absent from class and unable to study independently because they were not interested in learning [35]. However, the material presented in comics can increase the intensity of independent learning, attract attention and stimulate critical thinking. Students also responded that the $3 \mathrm{D}$ display by $\mathrm{AR}$ gave a good impression ranging from knowledge, ways of thinking to solve problems contained in the coordination system material. Thus, it is evident in this research that using comic books as AR markers can improve students' $\mathrm{CT}$ and get an excellent response.

\section{Conclusion}

This research concludes that comic books and AR meet their validity and use in learning during a pandemic and can improve students' CT. Recommendation for future research is trials on a large scale to determine the strong effectiveness of using comic books as AR markers. The results of this trial are still limited to AR, which can be installed on Android devices. This deficiency was found based on the limited-scale trials that have been carried out. Some students are using non-Android-based devices. The subsequent trial will make AR compatible with other devices.

\section{Acknowledgements}

The researcher is grateful for the funding of this research through the PDUPT grant by Kemendikbudristek (No: 177d/UN42.15/PG/2021).

\section{References}

[1]. Sari, R., Sumarmi, S., Astina, I., Utomo, D., \& Ridhwan, R. (2019). Measuring students scientific learning perception and critical thinking skill using paper-based testing: school and gender differences. International Journal of Emerging Technologies in Learning (IJET), 14(19), 132-149.

[2]. Sarwanto, S., Fajari, L. E. W., \& Chumdari, C. (2021). Critical Thinking Skills and Their Impacts on Elementary School Students. Malaysian Journal of Learning and Instruction, 18(2), 161-187.

[3]. Ozerbas, M. A., \& Erdogan, B. H. (2016). The effect of the digital classroom on academic success and online technologies self-efficacy. Journal of Educational Technology \& Society, 19(4), 203-212.

[4]. Puig, B., Blanco-Anaya, P., \& Pérez-Maceira, J. J. (2021, May). "Fake News" or Real Science? Critical Thinking to Assess Information on COVID-19. In Frontiers in Education (Vol. 6, p. 92). Frontiers.

[5]. Sprenger, D. A., \& Schwaninger, A. (2021). Technology acceptance of four digital learning technologies (classroom response system, classroom chat, e-lectures, and mobile virtual reality) after three months' usage. International Journal of Educational Technology in Higher Education, 18(1), 1-17.

[6]. Chaturvedi, S., Purohit, S., \& Verma, M. (2021). Effective Teaching Practices for Success During COVID 19 Pandemic: Towards Phygital Learning. Front. Educ. 6: 646557. doi: 10.3389/feduc.

[7]. Leinonen, T., Brinck, J., Vartiainen, H., \& Sawhney, N. (2021). Augmented reality sandboxes: children's play and storytelling with mirror worlds. Digital Creativity, 32(1), 38-55.

[8]. Önal, N. T., \& Önal, N. (2021). The effect of augmented reality on the astronomy achievement and interest level of gifted students. Education and Information Technologies, 26(4), 4573-4599. https://doi.org/10.1007/s10639-021-10474-7

[9]. Al Weshah, A., Alamad, R., \& May, D. (2020, February). Work-in-Progress: Using Augmented Reality Mobile App to Improve Student's Skills in Using Breadboard in an Introduction to Electrical Engineering Course. In International Conference on Remote Engineering and Virtual Instrumentation (pp. 313-319). Springer,

[10]. Chanjaradwichai, S., Na-Songkhla, J., \& Chiasiriphan, T. (2019). A Trackable Augmented Learning Media System for a Higher Education Level. International Journal of Emerging Technologies in Learning (iJET), 14(13), 129-144. 
[11]. Hedberg, H., Nouri, J., Hansen, P., \& Rahmani, R. (2018). A Systematic Review of Learning Trough Mobile Augmented Reality. International Journal of Interactive Mobile Technologies (iJIM), 12(3), 75-85.

[12]. Arici, F., Yildirim, P., Caliklar, Ş., \& Yilmaz, R. M. (2019). Research trends in the use of augmented reality in science education: Content and bibliometric mapping analysis. Computers \& Education, 142, 103647.

[13]. Sahin, D., \& Yilmaz, R. M. (2020). The effect of Augmented Reality Technology on middle school students' achievements and attitudes towards science education. Computers \& Education, 144, 103710.

[14]. Faridi, H., Tuli, N., Mantri, A., Singh, G., \& Gargrish, S. (2021). A framework utilizing augmented reality to improve critical thinking ability and learning gain of the students in Physics. Computer Applications in Engineering Education, 29(1), 258273.

[15]. Weng, C., Otanga, S., Christianto, S. M., \& Chu, R. J. C. (2020). Enhancing students' biology learning by using augmented reality as a learning supplement. Journal of Educational Computing Research, 58(4), 747-770.

[16]. Cihan, N. (2014). Eğitsel Araç Olarak Çizgi Romanin İlköğretim 8. Sinif Türkçe Ders Konularina Uyarlanmasi. Journal of Research in Education and Teaching, 3(3), 313-321.

[17]. Damopolii, I., Lumembang, T., \& Ílhan, G. O. (2021). Digital Comics in Online Learning During COVID-19: Its Effect on Student Cognitive Learning Outcomes. International Journal of Interactive Mobile Technologies, 33-47.

[18]. Lin, S. F., Lin, H. S., Lee, L., \& Yore, L. D. (2015). Are science comics a good medium for science communication? The case for public learning of nanotechnology. International Journal of Science Education, Part B, 5(3), 276-294.

[19]. Morel, M., Peruzzo, N., Juele, A. R., \& Amarelle, V. (2019). Comics as an Educational Resource To Teach Microbiology in the Classroom. Journal of microbiology \& biology education, 20(1), 20-1.

[20]. Lestari, F. P., Ahmadi, F., \& Rochmad, R. (2021). The Implementation of Mathematics Comic through Contextual Teaching and Learning to Improve Critical Thinking Ability and Character. European Journal of Educational Research, 10(1), 497-508.

[21]. Yusof, M. A. M., \& Masmuzidin, M. Z. (2021). Preserving Malaysian Folktales Through Mobile AR Application: Sumpahan Ikan Tapah. Journal of Computing Technologies and Creative Content (JTec), 6(2), 81-84.

[22]. Branch, R. M. (2009). Instructional design: The ADDIE approach (Vol. 722). Springer Science \& Business Media.
[23]. Mapeala, R., \& Siew, N. M. (2015). The development and validation of a test of science critical thinking for fifth graders. SpringerPlus, 4(1), 1-13.

[24]. Akbar, S. D. (2013). Instrumen Perangkat Perangkat Pembelajaran. Bandung: PT. Remaja Rosdakarya Offset.

[25]. Dunlap, W. P., Cortina, J. M., Vaslow, J. B., \& Burke, M. J. (1996). Meta-Analysis of Experiments With Matched Groups or Repeated Measures Designs. Psychological Methods, 1(2), 170-177.

[26]. Nusantari, E., Abdul, A., Damopolii, I., Alghafri, A. S. R., \& Bakkar, B. S. (2021). Combination of Discovery Learning and Metacognitive Knowledge Strategy to Enhance Students' Critical Thinking Skills. Combination of Discovery Learning and Metacognitive Knowledge Strategy to Enhance Students' Critical Thinking Skills, 10(4), 1781-1791.

[27]. Shariffudin, R. S., Azanan, S., \& Hsien, J. G. C. (2012). Multiple intelligence multimedia courseware (MIMCO) based on the constructivist-contextual model for the learning of some chemistry concepts. International Journal of Future Computer and Communication, 1(1), 29.

[28]. Iftene, A., \& Trandabăţ, D. (2018). Enhancing the attractiveness of learning through augmented reality. Procedia Computer Science, 126, 166-175.

[29]. Zafar, S., \& Zachar, J. J. (2020). Evaluation of HoloHuman augmented reality application as a novel educational tool in dentistry. European Journal of Dental Education, 24(2), 259-265.

[30]. Venkatesan, M., Mohan, H., Ryan, J. R., Schürch, C. M., Nolan, G. P., Frakes, D. H., \& Coskun, A. F. (2021). Virtual and augmented reality for biomedical applications. Cell Reports Medicine, 2(7), 100348.

[31]. Tagaytayan, R., Kelemen, A., \& Sik-Lanyi, C. (2018). Augmented reality in neurosurgery. Archives of medical science: AMS, 14(3), 572.

[32]. Astuti, T. N., Sugiyarto, K. H., \& Ikhsan, J. (2020). Effect of 3D Visualization on Students' Critical Thinking Skills and Scientific Attitude in Chemistry. International Journal of Instruction, 13(1), 151-164.

[33]. Billinghurst, M., \& Duenser, A. (2012). Augmented reality in the classroom. Computer, 45(7), 56-63.

[34]. Bakri, F., Vani, N. D., Permana, H., \& Muliyati, D. (2021, April). Textbook with augmented reality technology: Improve critical thinking skill in elasticity concept. In AIP Conference Proceedings (Vol. 2331, No. 1, p. 030036). AIP Publishing LLC.

[35]. Raiman, M., Liu, A. N. A. M. M., \& Wolo, D. (2021). Investigation of students' motivation to learn science while studying from home during a pandemic. Journal of Research in Instructional, 1(1), 33-42. 